\title{
Collaborative Writing: An Integration of Snack Bars and Hi-Five Fingers via Social Media
}

\author{
Yomana Chandran 1,2, Christina Jothi Plaindaren ${ }^{2,3}$, Shamini Pavadai' ${ }^{2}$, Melor Md. Yunus² \\ ${ }^{1}$ SMK Tasek Utara, Johor Bahru, Malaysia \\ ${ }^{2}$ Universiti Kebangsaan Malaysia, Bangi, Malaysia \\ ${ }^{3}$ SMK Abdul Rahman Talib, Kuantan, Malaysia \\ Email: pchrisj@yahoo.com,yomana.chandran@gmail.com, shaminip@live.com,melor@ukm.edu.my
}

How to cite this paper: Chandran, Y., Plaindaren, C. J., Pavadai, S., \& Yunus, M. Md. (2019). Collaborative Writing: An Integration of Snack Bars and Hi-Five Fingers via Social Media. Creative Education, 10, 475-484.

https://doi.org/10.4236/ce.2019.102034

Received: December 11, 2018

Accepted: February 25, 2019

Published: February 28, 2019

Copyright $\odot 2019$ by author(s) and Scientific Research Publishing Inc. This work is licensed under the Creative Commons Attribution International License (CC BY 4.0).

http://creativecommons.org/licenses/by/4.0/

\begin{abstract}
English has been the second language taught in schools in Malaysia both in primary and secondary level. Writing skill has been a major part of the English education in the Malaysian schools. However, writing skill is the most difficult skill to master by our Malaysian pupils. Both teachers and pupils find teaching and learning of writing a difficult task to accomplish in the classroom. This can be caused by the lack of teacher-pupil time in school. Teachers do not have time to give feedback to pupils after they have written their essay. Thus, the writing skill was taught out of the classroom contact hours using social media. Therefore, the aim of this action research is to help the Secondary Four pupils use the hi-five Fingers and Snack Bars via social media (Powtoon and Facebook) in their writing to achieve better results. The activities were conducted on 55 participants located in two different schools in Kuantan, Pahang and Johor Bahru, Johor. The study involved two different approaches namely, Product-based and Process-based. The instruments used in this research are pretest, posttest and face-to-face interview. The findings have shown that there is an improvement in pupils' grades in their writing performance after using the hi-five fingers and snack bars via social media. Thus, it is evident that the usage of hi-five fingers and snack bars via social media in collaborative writing is essential to increase pupils' writing skill and ability.
\end{abstract}

\section{Keywords}

Collaborative, Social Media, Facebook, Powtoon, Writing

\section{Introduction}

Language is a mean of interaction in a community. It is known as a fundamental 
element and the most common feature in a community. Precisely, in a multiracial society like in Malaysia and Singapore, they have a variety of languages to communicate with. To begin the list, in Malaysia, the Malay language as the national language and next, English language is known as the second language which is taught in schools in Malaysia for both, primary and secondary level which involves four main skills namely, listening, speaking, reading and writing. Writing skill is the main skill assessed in Malaysian schools. In Malaysia's major examination, the Sijil Pelajaran Malaysia (SPM), writing is the main skill assessed. There are two papers in this examination. Paper one tests solely on pupils' writing skill. Pupils are required to write two essays in this paper which are, Directed Writing and Continuous Writing. As for the Directed Writing, pupils are required to write about 250 words while for the Continuous Writing, pupils are required to write more than 350 words. This paper contributes 80 marks of the whole paper which is, 155 marks. Thus, more than $50 \%$ of the grade comes from this paper which proves the point that a huge focus needs to be given on teaching the writing skill to the pupils.

However, writing skill is the most difficult skill to master by our Malaysian school pupils (Ien, Yunus, \& Embi, 2017). Both teachers and pupils find teaching and learning of writing a difficult task to accomplish in the classroom (Akinwamide, 2012). Many pupils find it difficult to write a good essay in English despite learning the language for a good 10 years in the primary and secondary schools in Malaysia. According to Maghsoudi \& Haririan (2013), writing in English is difficult because it requires them to apply cognitive and linguistic strategies that pupils are not sure of. Yunus and Chien (2016) state that in order for a writer to be competent he or she must have a comprehensive knowledge of grammar, have a vast choice of vocabulary, know writing mechanics and have varied writing styles. Pupils also cannot generate ideas and they find it difficult to write paragraphs, which is identified as major problems (Firmansyah, 2015). Yunus \& Chan (2016), also state that pupils find it difficult to write due to the lack of opportunities to practice writing. This is due to time constraint and minimal contact hours in classroom. There is no enough time to interact and discuss the weaknesses that pupils have in language acquisition. Teachers do not have time to give feedback to pupils after pupils have written their essay. Thus, pupils do not have the time and knowledge to correct the errors they have made in their writing, making writing a difficult task to accomplish.

According to Ien, Yunus and Embi (2017), literacy is vital in preparing out pupils to achieve personal growth and confidence to become better people in the society. Therefore, the teaching of writing using snack bars and hi-five fingers via social media will help to overcome this gap as pupils will be able to write outside the classroom at their own time and space. The pupils will also be able to receive feedback from three different teachers and peers as it is a collaborative learning of writing. Many studies have been carried out in the classroom for the teaching and learning of writing. However, the integration of writing snack bars 
and hi-five fingers via social media can be carried out in both inside and outside the classroom. The aim of this research is to explore the integration of writing snack bars and hi-five fingers in collaborative writing through social media among the Form Four pupils.

\section{Literature Review}

\subsection{Teaching of Writing}

Writing skill, has always been a challenge for second language learners. To come up with a good piece of writing, learners need to stay focused. This situation has caused the learners to think about writing as a boring activity, especially for those who have difficulties in linguistics, psychology and cognitive problems. Hence, an alternative way is needed to increase second language learners' interest in the writing skill. According to Dar \& Khan, 2015; Hyland, 2003; Mahboob, 2015 , writing requires appropriate and strategic use of language with structural accuracy and communication. There are various stages in the writing skill that have caused the first and second language learners to have poor writing skill (Stapa \& Majid, 2012).

\subsection{Collaborative Writing}

Collaborative writing for this study refers to a task that is carried out together by a group of people where the process and the responsibility in producing a text is done collaboratively (Storch, 2013: p. 3). Hayes (1996) suggests that a writing communicative requires a social contact and communication. According to Storch (2005), researchers have taken note the importance of preparing learners to engage in the collaborative writing process. Teachers should know their role in facilitating collaborative writing with the use of technology. Hence, collaborative writing using social media can assist pupils in developing the content (Kessler, 2009).

\subsection{Collaborative Writing and the Integration of Social Media}

Pupils' writing ability can be improved by building their interest, motivation and enjoyment in writing through technology (Graham \& Perin, 2007). The study by Smith, Pacheco \& de Almeida (2017) shows that when pupils are given a task to write in an informal environment, they are able to express their ideas and opinions more effectively. Pupils are more interested to be focused in writing when they write their essays out of the traditional norms. Thus, social media is one of the most popular educational media in the current world.

In addition, social media plays as a visual medium that helps teachers to convey messages to help pupils to understand the concept of learning materials easily. Besides, social media is an easily accessible tool and fun to be used flexibly. As stated by Sudjana, Rifai (2005), the message that is sent through communication symbols and is expected to excite and give confidence as well as motivation to the pupils to participate actively in the learning process. 
Hamalik (1996: p. 46) advocates that the use of media in the learning process will be able to generate new desires and interests, and encourage motivation and stimulation in all learning activities. Thus, social media raises pupils' motivation to learn and play as a tool of communication in conveying message to pupils in a more flexible and easier way.

\section{Methodology}

\subsection{Research Design}

An action research (the model of Kemmis and McTaggart) was chosen. Action research is all about what happens in the classroom. It was employed in both the schools to carry out collaborative writing using hi-five fingers and writing snack bars via social media (Powtoon and Facebook). An action research is the most applied, practical design which explores a practical problem towards developing a solution towards a problem Creswell (2014). In this study, the researchers have explored a practical problem in the teaching of writing and developed a method as a solution to this problem. The study is a qualitative research which used pretest and posttest.

Diagram 1 shows the action research based on the model of Kemmis and McTaggart where the processes involved in the research was planning, carrying out an action, observing and reflecting. The steps were then repeated.

The rationale of this study is to teach collaborative writing by integrating the use hi-five fingers and writing snack bars via technology (Powtoon and Facebook) to master the writing skills. A pretest was carried out on Facebook where a group was created and pupils from both schools were enrolled in it as members. The pupils were given a writing task on continuous writing in the group. Pupils were given a topic on cause and effects of cyberbullying and they were asked to write the essay in two days. Pupils wrote the essay and sent it in to their respective teachers. Pupils essay was assessed using the marking scheme for English SPM paper 1.

An intervention was carried out. The hi-five fingers were introduced to the

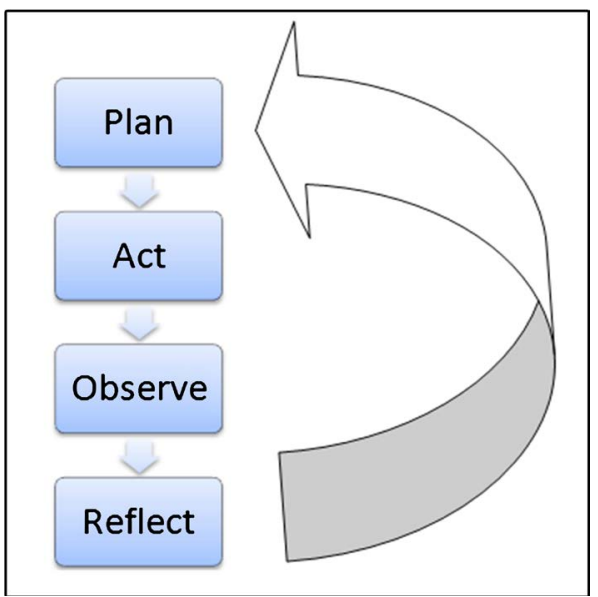

Diagram 1. Model of Kemmis and McTaggart. 
pupils and a brainstorming session was carried out in class. Content points for the topic were discussed. Pupils had to list down five points for their essay on the hi-five fingers. Next, pupils were introduced to the writing snack bars which consist of ways to write an introductory paragraph, topic sentences, concluding sentences, star ideas and elaborations. Pupils were then given videos on the snack bars, to watch on Facebook. Then, using the steps given in the writing snack bar, pupils wrote their essays one paragraph at a time. Pupils posted their paragraphs on Facebook to get feedback from their teachers and peers. The feedback was used to write the paragraph again correctly. Pupils corrected their mistakes by referring to the feedback given. This step was repeated for all the paragraphs until the essay was completed. For the posttest, pupils were asked to write another similar essay on the causes and effects of social media

\subsection{Respondents}

A total of 55 numbers of Secondary Four pupils are from two schools namely, SMK, Tasek Utara, Johor Bahru, Johor and SMK. Abdul Rahman, Kuantan, Pahang were involved in the study. There were 19 male pupils, which makes up to $35 \%$ of the sample population and 36 female pupils which makes up to $65 \%$ of the sample population.

\subsection{Instrument}

The instruments used were pretest, posttest and interview. The pretest was aimed to test the pupils' prior knowledge before the intervention was carried. The posttest was aimed to measure the pupils' grades in writing after the intervention. The face-to-face interview was carried out with the pupils to determine whether the intervention was useful in learning of writing.

\subsection{Procedure}

A total of 55 Form Four pupils were chosen to be the participants using the purposive sampling method. The research was conducted in a time frame of three months. Alongside with the objective of the research, three instruments were used, namely pretest, posttest and face-to-face interview to collect the designated information needed for the research. The participants were given the similar essay question for their pretest and posttest.

During the pretest and posttest stage, the Product-based approach was used. Pupils were given a topic to write on. Pupils had to complete their task and send in the final product to the teacher. During the intervention stage, pupils were taught to use the hi-five fingers to brainstorm ideas and snack bars to guide the stages of their essay. After which, the writing process was accomplished paragraph after paragraph. The samples were required to post their writings on the Facebook group that had been created for peer and teacher feedback session. As the intervention followed the Process-based approach precisely, thus the importance of feedback session was emphasized by the respective teachers as they 
administer the research. Both the tests were graded according to the same standardized descriptors by the Ministry of Education for Sijil Pelajaran Malaysia. A comparison was made between the grades that the pupils had obtained during the pretest and posttest after the intervention was carried out. An interview was carried out using a semi-structured interview to check the effectiveness of using high-five fingers and snack bars via social media to teach collaborative writing. The findings will be discussed further in the next section of this paper (Diagram 2).

\subsection{Data Analysis}

The results of the pretest and posttest were also incorporated with the face-to-face interview to get the findings of the study. The essays written by the pupils in the pretest and posttest were analysed using the SPM Paper 1 marking scheme. The marking scheme is a standardized nationwide document used to assess the pupils' writing task. The face-to-face interview using a semi-structured interview was carried out and analysed to obtain feedback from the pupils on the study.

\section{Findings}

The findings were based on three instruments, pretest, posttest and face-to-face interview. The findings show that the use of high-five fingers and snack bars via social media to teach collaborative has no only increased pupils' grades but also, the attitude of pupils towards learning writing.

\section{Pretest}

Pupils' essay was assessed using the marking scheme for English SPM paper 1. A lot of errors were made by pupils (Table 1).

Pupil's lack of knowledge in sentence structure is evident as the pupil has written two simple sentences which could have been made into one compound sentence. Subject-verb agreement and tenses was also used wrongly by most pupils.

\section{Post test}

For the posttest, pupils were asked to write another essay on the causes and effects of social media. Pupils could write their essay and less errors were made.

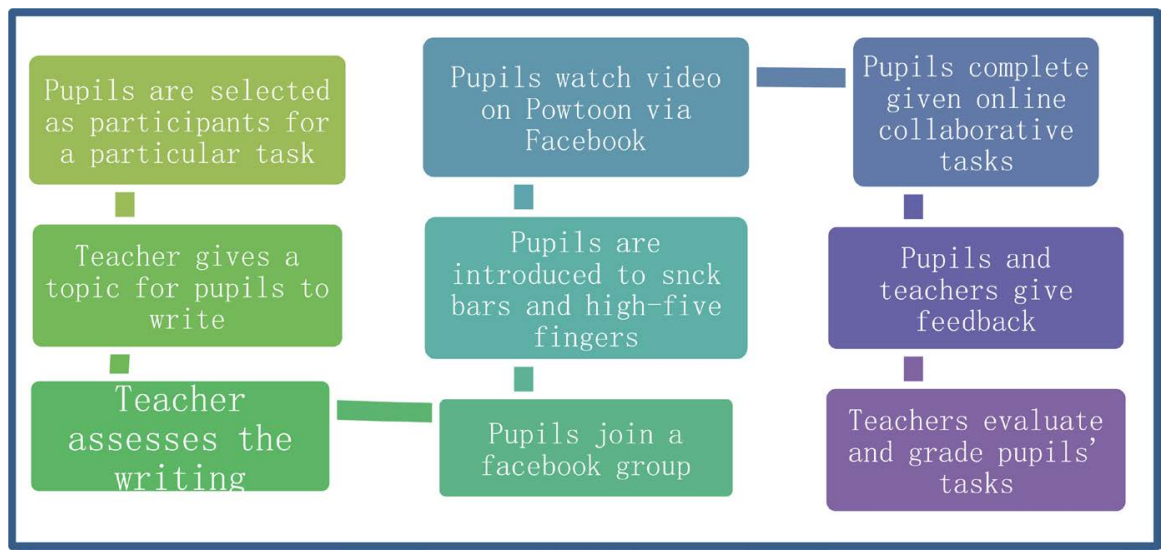

Diagram 2. The procedures carried out. 
Their points were more organized and contained more elaboration. Pupils also could write better introductory paragraphs by using questions, statements, and newspaper headlines. The scores for pretest and posttest were compared.

Table 2 shows the pre-test scores and post test scores of pupils in both schools. There is an increase in the post test scores after intervention was carried out. For school A, the mean of pre test scores is 23.5 where else for school B the mean for pre test scores is 22.4. There is an increase in the mean for both schools in their posttest, where, school A has a mean of 27.4 and school B has a mean of 26.8 .

\section{Face-to-face interview}

It is undeniable that writing is the most difficult task compared to all the other skills. A face to face interview was carried out on 20 pupils of both schools. 6 questions were prepared by the teachers. The interview was carried out in the school after the posttest was carried out. The interview shows that the collaborative writing between two schools has helped pupils to make friends. Besides, peer feedback has helped pupils to improve their writing. As quoted by Samhita,

"I have made new friends from a state I have not been to. I have received feedback from friends and it has helped me to improve my writing. I still keep in touch with some of them."

Table 1. Errors made by pupils in the posttest.

\begin{tabular}{|c|c|c|}
\hline Elements & Errors & Examples \\
\hline $\begin{array}{l}\text { Sentence } \\
\text { Structure }\end{array}$ & $\begin{array}{l}\text { - Use of simple sentences } \\
\text { - No use of compound and complex }\end{array}$ & $\begin{array}{l}\text { The main cause of cyberbullying is to } \\
\text { gain attention. } \\
\text { Parents are busy with work. } \\
\text { Depression can lead to suicide. } \\
\text { Depression can also lead to self-doubt. }\end{array}$ \\
\hline $\begin{array}{l}\text { Subject-Verb } \\
\text { Agreement }\end{array}$ & - Use of the wrong verb & $\begin{array}{l}\text { The reason cyberbullying occur is } \\
\text { because of revenge. } \\
\text { The cyberbullying usually aim for } \\
\text { someone who is weaker. }\end{array}$ \\
\hline Tenses & - Use of wrong tenses & $\begin{array}{l}\text { They will be stress out. } \\
\text { Respect other people like how we } \\
\text { wanted to be treated. }\end{array}$ \\
\hline Spelling & - Wrongly spelled & $\begin{array}{l}\text { Cyber bully } \\
\text { Behavior } \\
\text { Acess }\end{array}$ \\
\hline
\end{tabular}

Table 2. Comparison of results in pretest and posttest (Qualitative Data).

\begin{tabular}{ccccc}
\hline School & $\begin{array}{c}\text { Pre-test scores of } \\
55 \text { students }\end{array}$ & $\begin{array}{c}\text { Mean of pre-test } \\
\text { scores }\end{array}$ & $\begin{array}{c}\text { Post test scores of } \\
55 \text { students }\end{array}$ & $\begin{array}{c}\text { Mean of post test } \\
\text { scores }\end{array}$ \\
\hline School A (28) & 658 & 23.5 & 766 & 27.4 \\
School B (27) & 604 & 22.4 & 725 & 26.8 \\
\hline
\end{tabular}


The usage of the high-five fingers and snack bars has also helped pupils to organize their ideas and write creative and interesting introduction and content paragraphs. Eizah Risma pointed out,

"I always have difficulties organizing my points. I also always don't know how to start a paragraph. The high five fingers has taught me to organize my ideas and the snack bars has taught me to write better introduction and content paragraphs. I now know how to start my essay!"

When pupils were asked what were their feelings before and after the intervention was carried out, pupils voiced out their opinion. Quoted by one of the respondents, Rishen,

"I often felt stressed out to write in the classroom because it was boring and I did not have enough time to write. But, now using Facebook, I can write anytime and anywhere I want. I can take my time, create ideas and write."

From the feedback given by the pupils, they had mentioned that they have found out on how to write an introductory paragraph using questions, newspaper headlines and statements. They had also mentioned that they could organize their points well by using the hi-five fingers. This has proven that the pupils have started feeling more confident in writing after knowing the two methods. Besides, the pupils have also said that the use of Powtoon videos and Facebook have attracted them towards learning of writing compared to the conventional method of learning it in the classroom through chalk and talk method. As the task carried out was fun, pupils' interest to write also escalated. Thus, the use of high-five fingers and snack bars via social media to teach collaborative writing, has not only increased pupils grades, but also, the attitude of pupils towards learning writing.

\section{Limitation and Recommendation}

This study aims to find out whether the collaborative writing using the integration of writing snack bars and hi-five fingers through social media can enhance writing skill among the Form Four pupils. However, this study has a few limitations. Firstly, the pupils' accessibility to the internet as it is a primary factor that needed to be present throughout this study. Secondly, since the study had involved two different states, thus the issue on inferiority complex was evident. However, it took some time to subside as the timeline for the study was short and limited. A research can be carried out to further study about the use of collaborative writing in rural schools where social media is not accessible.

\section{Implications}

From the study above, the collaborative writing which uses the integration of high-five fingers and snack bars via social media has shown that the quality of writing in pupils has improved. The engagement of students in a collaborative class has also increased the pupils' interest to write. Pupils and teachers get to be a virtual classroom while the teaching and learning process takes place. Time 
will not be a factor in teaching writing skills as the teaching and learning process can take place out of the classroom, anywhere and anytime. Pupils now not only have fun in their writing classroom but their grades have also improved.

\section{Discussion and Conclusion}

Therefore, the English language teachers of this modernized era should come up with innovative and technological-based teaching methods to enhance the pupils' learning experience and it should not be confined to a classroom solely but beyond that. Such appropriate and efficient teaching tools would ensure the accelerated scoring of grades among the pupils. As Kessler (2009) states, collaborative writing using technology in this case, the social media, can help pupils in content development. Through this study, the use of these tools has helped to increase the results of the pupils in their writing. Pupils' writing ability can be improved by fostering their interest, motivation and enjoyment for writing, through technology (Graham \& Perin, 2007). When the teachers start breaking the wall of classrooms to widen the horizon of learning for the pupils, the pupils would eventually leave their cocoon respectively to learn from outside their comfort zone.

\section{Conflicts of Interest}

The authors declare no conflicts of interest regarding the publication of this paper.

\section{References}

Akinwamide, T. K. (2012). The Influence of Process Approach on English as Second Language Pupils' Performance in Essay Writing. ELT, 5, 16-29.

Creswell, J. W. (2014). Research Design: Qualitative, Quantitative and Mixed Methods Approaches (4th ed.). Lincoln: University of Nebraska-Lincoln.

Dar, M. F., \& Khan, I. (2015). Writing Anxiety among Public and Private Sectors Pakistani Undergraduate University Students. Pakistan Journal of Gender Studies, 10, 121-136.

Firmansyah, A. (2015). The Influence of Mind Mapping Technique and Students' Attitude toward Students' Ability in Writing a Recount Text of the Eighth Grade Students of State Junior High School 45 Palembang. RIPTEKSI KEPENDIDIKAN PGRI.

Graham, S., \& Perin, D. (2007). Writing Next: Effective Strategies to Improve Writing of Adolescents in Middle and High Schools-A Report to the Carnegie Corporation of New York. Washington DC: Alliance for Excellence in Education.

Hamalik, O. (1996). Media Education. Bandung: PT Citra Aditys Bakti.

Hayes, J. (1996). A New Framework for Understanding Cognition and Affect in Writing. In C. M. Levy, \& S. Ransdell (Eds.), The Science of Writing: Theories, Methods, Individual Differences, and Application. Mahwah, NJ: Lawrence Erlbaum Associates.

Hyland, K. (2003). Second Language Writing. Cambridge: Cambridge University Press.

Ien, L. K., Yunus, M. M., \& Embi, M. A. (2017). Overcoming Writing Problems among Pupils in a Rural Primaty School in Belaga Sarawak, Malaysia. Bangi: Universiti Kebangsaan Malaysia. http://journal.um.ac.id/index.php/jph 
Kessler, G. (2009). Student Initiated Attention to Form in Autonomous Wiki Based Collaborative Writing. Language Learning \& Technology, 13, 79-95.

http://lit.msu.edu/vol13num1 /kessler.pdf.

Maghsoudi, M., \& Haririan, J. (2013). The Impact of Brainstorming Strategies Iranian EFL Learners Writing Skill regarding Their Social Class Status. Journal of language and linguistics, 1, 60-67. https://doi.org/10.11648/j.ijll.s.20130101.20

Mahboob, A. (2015). Understanding and Providing Cohesive and Coherent Feedback on Writing. Journal of Writing \& Pedagogy, 7, 2-3.

Smith, B. E., Pacheco, M. B., \& de Almeida, C. R. (2017). Multimodal Codemeshing: Bilingual Adolescents' Processes Composing across Modes and Languages. Journal of Second Language Writing, 36, 6-22. https://doi.org/10.1016/j.jslw.2017.04.001

Stapa, S. H., \& Majid, A. H. A. (2012). The Use of Scaffolding Technique via Facebook in Improving Descriptive Writing among ESL Learner. The Southeast Asian Journal of English Language Studies, 23, 77-88.

Storch, N. (2005). Collaborative Writing: Product, Process, and Students' Reflections. Journal of Second Language Writing, 14, 153-173.

Storch, N. (2013). Collaborative Writing in L2 Classrooms: New Perspectives on Language \& Education (Vol. 31). Bristol: Multilingual Matters. https://doi.org/10.21832/9781847699954

Sudjana, N., \& Rifai, A. (2005). Teaching Media. New York: New Light Algesindo.

Yunus, M. M., \& Chien, C. H. (2016). The Use of Mind Mapping Strategy in Malaysian University English Test (MUET) Writing. Creative Education, 7, 619-626.

https://doi.org/10.4236/ce.2016.74064 